\title{
Floral Resources Used by Euglossini Bees (Hymenoptera: Apidae) in Coastal Ecosystems of the Atlantic Forest
}

\author{
L. C. Rocha-Filho, ${ }^{1}$ C. Krug, $^{2}$ C. I. Silva, ${ }^{1}$ and C. A. Garófalo ${ }^{1}$ \\ ${ }^{1}$ Departamento de Biologia, Faculdade de Filosofia, Ciências e Letras de Ribeirão Preto (FFCLRP), Universidade de São Paulo (USP), \\ Avenida Bandeirantes 3900, 14040-901 Ribeirão Preto, SP, Brazil \\ ${ }^{2}$ Empresa Brasileira de Pesquisa Agropecuária, CPAA, Rodovia AM-10, Km 29, Zona Rural, Caixa Postal 319, 69010-970 Manaus, \\ AM, Brazil
}

Correspondence should be addressed to L. C. Rocha-Filho, correiadarocha@yahoo.com.br

Received 16 July 2012; Accepted 28 August 2012

Academic Editor: Kleber Del-Claro

Copyright $\odot 2012$ L. C. Rocha-Filho et al. This is an open access article distributed under the Creative Commons Attribution License, which permits unrestricted use, distribution, and reproduction in any medium, provided the original work is properly cited.

In spite of playing an important ecological role as pollinators of tropical ecosystems, orchid bees are still poorly known regarding their floral resources. Aiming at a better comprehension of the importance of different plants visited by the Euglossini and, consequently, their role in the maintenance and reproduction of plant species in tropical ecosystems, this study aimed at identifying the flowers visited by those bees in two different areas of the Atlantic Forest in the northern coast of the state of São Paulo, Brazil. Sampling was carried out from August 2007 to July 2009 in two coastal ecosystems in Ubatuba, Brazil. In order to obtain information on flower resources collected by Euglossini bees in loco, all bees observed on flowers were collected, pollinaria of Orchidaceae occasionally attached to the body of males were identified, and the pollinic analysis of 68 females was carried out. One hundred twelve bees from 14 species were associated to 105 plant species which represented pollen, nectar, resin, and fragrances sources. These data reinforce the relevance of orchid bees to the maintenance and reproductive success of many tropical plants.

\section{Introduction}

There is evidence that Euglossini bees play an important ecological role in the maintenance and reproductive success of a wide range of plant species in tropical ecosystems [13]. Females visit the plants to collect resin, which is used for nest building as well as nectar and pollen, which are used for provisioning brood cells [4-10]. They have specific foraging routes, known as "traplines," which are followed for several days such that the same flowering plant specimens are visited in a particular sequence. This behaviour implies fidelity to collection sites, and Janzen [11] reported that the females can fly considerable distances quickly, which ensures that a given foraging route can cover a large area. This observation by Janzen [11] is related to the fact that the plants producing food are often widely dispersed in a given area and produce few flowers per day, offering high-quality resources over long periods. Similar to females, Euglossini males are also able to fly quickly and over long distances in search of resources to meet their needs [11-13] and may feed on nectar from the same plants utilised by females [4].

It is estimated that approximately $10 \%$ of the 600 to 700 species of the Orchidaceae family are pollinated exclusively by male orchid bees, who visit them to collect floral fragrances [14-17]. These aromatic substances are also collected from plants of several other families, such as Gesneriaceae [18]; Araceae [19]; Euphorbiaceae [20]; Haemodoraceae [21]; Apocynaceae, Loganiaceae, and Malvaceae [22]; Solanaceae [23]; Pentaphylacaceae [24]; Lecythidaceae [25]; Clusiaceae [26]; Amaryllidaceae [27], Bromeliaceae [28], Annonaceae [29], and Plantaginaceae [30], and are stored by males in their modified hind tibias $[31,32]$ to be released later, presumably to attract females for mating $[33,34]$.

Plant species from several families have Euglossini as their primary pollinators due to the morphological, ecological, and behavioural characteristics of these bees, including their long tongue, the use of resin for nest construction, the 
female behaviour of buzz-pollination, and the collection of floral fragrances by males [35-40].

Information on the flora visited by the Euglossini is based on direct observations made in loco $[35,41]$ that are dispersed among bee surveys and studies on plant reproductive biology, many of which are gathered in compilations of data such as the study by Ramírez et al. [42]. It is notable that techniques such as pollen analysis that provide information about the floral resources collected by bees through indirect evidence have been little explored in studies involving Euglossini species [43-45]. Knowledge of the floral resources utilised by the orchid bees enables a better understanding of the importance of the different plants visited during the life cycle of these bees and, consequently, their role in the reproductive biology and maintenance of plant species in tropical ecosystems.

Interaction networks between plants and insects have been used to represent plant-pollinator relationships and to describe the processes, structure, and generalisations of these networks [46, 47]. According to Bezerra et al. [48], the ecological service of pollination is composed of a mosaic of different subservices with a hierarchical structure, of networks within networks, which is particularly evident in phylogenetic groups. Thus, the present study aimed to identify the floral resources collected by Euglossini bees in two Atlantic Forest areas on the northern coast of São Paulo.

\section{Materials and Methods}

2.1. Study Areas. Samplings were conducted monthly between 9:00 and 15:00 in the period from August 2007 to July 2009 in two areas: the Picinguaba area of Parque Estadual da Serra do Mar (PESM) and Parque Estadual da Ilha Anchieta (PEIA).

The PESM $\left(23^{\circ} 21^{\prime} 51.7^{\prime \prime} \mathrm{S}, 44^{\circ} 49^{\prime} 56.9^{\prime \prime} \mathrm{W}\right)$ has a total area of 47,500 ha, which contains practically all of the ecosystems that are representative of the Atlantic Forest biome, from mangroves and highly diverse coastal plain vegetation to small areas of high altitude grasslands at its highest elevations, such as the "Pedra do Espelho" $(1670 \mathrm{~m})$ and the peaks of Corcovado $(1150 \mathrm{~m})$ and Cuscuzeiro $(1275 \mathrm{~m})$ in Ubatuba. The Picinguaba area is the only stretch of the PESM that reaches sea level, thus protecting coastal ecosystems.

The PEIA $\left(23^{\circ} 32^{\prime} 25.0^{\prime \prime} \mathrm{S}, 45^{\circ} 04^{\prime} 15.5^{\prime \prime} \mathrm{W}\right)$ covers a total area of 828 ha, which corresponds to the full extent of Anchieta Island, which is separated by approximately $600 \mathrm{~m}$ from the mainland. Many ecosystems of the Atlantic Forest are also present on the island, and the vegetation of these areas was described by Guillaumon et al. [49] and follows Rizzini [50]: anthropic fields (Campo antrópico), whose dominant vegetation is herbaceous and most commonly found families are Poaceae, Melastomataceae, and some ferns; rocky shore, characterised by the predominance of herbaceous and thin vegetation, with high indices of humidity and luminosity, and whose most common families are Araceae, Marantaceae, Sapindaceae, Rubiaceae, Piperaceae, Bromeliaceae, Fabaceae, Cactaceae, and Arecaceae; Atlantic Forest: dense Atlantic Forest in the northeast sector of the island and thin Atlantic
Forest in the southwest, which are predominantly composed of the families Fabaceae, Arecaceae, Rubiaceae, Melastomataceae, Meliaceae, Salicaceae, Clusiaceae, Araceae, Malvaceae, Bignoniaceae, Piperaceae, Polypodiaceae, and Urticaceae; Gleichenia areas: dense patches of vegetation consisting of individuals of the Gleicheniaceae family; mangroves: vegetation that is not very substantial, with some individuals of Avicennia L. (Acanthaceae) and Acrostichum L. (Pteridaceae); restinga: a coastal vegetation that varies from sparse to transitional broadleaf forest, and whose most commonly observed families are Bromeliaceae, Myrtaceae, Anacardiaceae, Cyperaceae, Araceae, Cactaceae, Poaceae, Fabaceae, Arecaceae, Polypodiaceae, and Gleicheniaceae [51].

2.2. Samplings of Bees. Three sampling methods were used in order to identify the floral sources visited by orchid bees: sampling of males using scent baits, observations, and collections of both females and males on flowers and the pollen analysis of females collected both on flowers, in flight or at scent baits.

Male bees' samplings by scent baits were performed along two distinct trails: the "Picadão da Barra" Trail $\left(23^{\circ} 21^{\prime} 51.7^{\prime \prime} \mathrm{S}, 44^{\circ} 49^{\prime} 56.9^{\prime \prime} \mathrm{W}\right.$, altitude $\left.3 \mathrm{~m}\right)$, which was used in the first year of study between August 2007 and July 2008, and the "Guanambi" Trail $\left(23^{\circ} 21^{\prime} 37.0^{\prime \prime} \mathrm{S}, 44^{\circ} 50^{\prime} 52.9^{\prime \prime} \mathrm{W}\right.$, altitude $3 \mathrm{~m}$ ), where censuses were conducted in the second year, between August 2008 and July 2009. As in the Picinguaba area, two trails were utilised for the census of males with scent baits: in the first year, the "Praia das Palmas" Trail $\left(23^{\circ} 32^{\prime} 25.0^{\prime \prime} \mathrm{S}, 45^{\circ} 04^{\prime} 15.5^{\prime \prime} \mathrm{W}\right.$, sea level) and, in the second year of samplings, the "Represa" Trail $\left(23^{\circ} 32^{\prime} 27.3^{\prime \prime} \mathrm{S}\right.$, $45^{\circ} 03^{\prime} 58.9^{\prime \prime} \mathrm{W}$, altitude $18 \mathrm{~m}$ ).

To obtain information on the floral resources collected by both females (pollen, resin, and nectar) and males (nectar and floral fragrances), all of the flowering species present within $50 \mathrm{~m}$ of the trails used for the collection of males with scent baits were observed, monitored, and identified. The collection behaviour of bees as well as the resources collected was also recorded.

2.3. Pollinaria. During the screening of the collected material, Orchidaceae pollinaria that were occasionally found attached to the bodies of the males were removed and placed in individual vials containing $70 \%$ alcohol for preservation and identification.

2.4. Pollen Analysis. Due to the scarcity of pollen grains in males, pollen analysis was performed only for the 68 collected females, which were distributed among nine species: Eufriesea dentilabris (Mocsáry, 1897) $(N=2)$, Eufriesea smaragdina (Perty, 1833) $(N=1)$, Eufriesea surinamensis (Linnaeus, 1758) $(N=1)$, Euglossa cordata (Linnaeus, 1758) $(N=8)$, Euglossa stellfeldi (Moure, 1947) $(N=5)$, Euglossa townsendi (Cockerell, 1904) $(N=1)$, Eulaema cingulata (Fabricius, 1804) $(N=4)$, Eulaema helvola (Moure, 2003) $(N=4)$, and Eulaema seabrai (Moure, 1960) $(N=46)$. The contents of the corbiculae of these females were removed with forceps and placed in vials containing absolute glacial 
acetic acid for subsequent mounting on slides for light microscopy according to the acetolysis protocol described by Erdtman [52]. After the process of acetolysis, pollen grains were placed in test tubes containing $50 \%$ glycerine for at least 24 hours. Small amounts of acetolysed material were deposited on slides containing glycerol gelatine.

To identify the types of pollen on the slides, samples were collected from the anthers of herbarium specimens deposited at the Herbarium of the Universidade Estadual de Campinas (UEC), the Herbarium Rioclarense (HRCB), and the Herbarium of the Departamento de Biologia da Faculdade de Filosofia, Ciências e Letras de Ribeirão Preto (SPFR). The identification of the pollen grains as pollen, resin, or nectar sources was carried out based on the occurrence of the pollen types at the slides and also according to the floral morphology and the available floral resources of the plant species. The morphology of orchid bee species and literature information concerning their collection behaviour on flowers were also considered. Many of these herbarium specimens came from floristic surveys and/or collections conducted in Ubatuba, around Picinguaba and on Anchieta Island, and were accessed through the SpeciesLink network database [53]. The slides made with the anthers removed from herbarium specimens as well as those with anthers collected locally, were deposited at the Laboratório de Palinoecologia of the Departamento de Biologia da Faculdade de Filosofia, Ciências e Letras de Ribeirão Preto.

2.5. Interaction Networks. Interaction networks were constructed using qualitative interaction matrices for Euglossini males and females and the plants that these bees used as resources. In the matrices, the rows represented plant species and the columns represented the bee species. The matrices recorded the presence (1) or absence (0) of an interaction between a given plant and a bee species. Collections of resin and fragrance were also considered interactions. Networks representing the interactions established between bees and pollen sources (females only) and nectar (males and females) were also analyzed to better assess the types of interactions established. Resin and fragrance were not plotted because both resources occurred in a few interactions and they were only represented at Figure 1. The significance of NODF was estimated using a Monte Carlo procedure with 1000 randomizations using the null model $\mathrm{Ce}$ in the computer software ANINHADO 3.0 [54]. The interaction networks were constructed in the form of bipartite graphs by the bipartite package of the $\mathrm{R}$ program [55]. Connectance was also calculated using the same package. Because collections were carried out in the same biome (Atlantic Forest) using the same methodology and sampling effort, the data were analysed together.

\section{Results}

3.1. Observations in Flowers. In the Atlantic coastal ecosystems studied, 112 bees were collected belonging to 14 species, which were associated with 105 species of plants. Ten Euglossini species, represented by 79 individuals, were sampled in a total of 21 plants in the Ubatuba region (Table 1). In Picinguaba, ten bee species were sampled: Ef. dentilabris, Ef. surinamensis, Euglossa iopoecila Dressler, 1982, Eg. stellfeldi, Eg. townsendi, El. cingulata, and El. seabrai, whereas on Anchieta Island, the species Ef. smaragdina, Eg. cordata, Eg. stellfeldi, El. cingulata, El. helvola, and El. seabrai visited the flowers of ten plants. In addition to the two areas studied, there is also a record of El. seabrai males on inflorescences of Anthurium andraeanum at the base of the Instituto Oceanográfico da Universidade de São PauloIO/USP, located near the "Saco da Ribeira" marina, which is the point of access for Anchieta Island.

Regarding the floral resources collected, five species of flowers were visited exclusively by females to collect pollen, and 15 plants were used as sources of nectar for both males and females (Table 1). On Anchieta Island, in addition to the native species of the Atlantic Forest biome, exotic plants were also visited by Euglossini bees to collect floral resources. These exotic species included ornamental Alpinia zerumbet, Thunbergia alata, and Impatiens walleriana as well as papaya, Carica papaya.

3.2. Pollinaria. Of the 1503 males collected in artificial baits [56], only $32(2.13 \%)$, represented by eight species, carried pollinaria of ten Orchidaceae species (Table 2). Ten orchid species from eight genera were identified, and only the pollinaria of Catasetum hookeri and Cirrhaea fuscolutea were found in males from more than one Euglossini species (Table 2). With the exceptions of Catasetum hookeri, Catasetum socco, Cirrhaea dependens, and Cirrhaea fuscolutea, all other orchids were found exclusively in one study area (Table 2). All species of Orchidaceae found in the present study provide only floral fragrances as a resource for male Euglossini visiting their flowers (R. B. Singer, pers. comm.).

3.3. Pollen Analysis. Of the 68 females whose pollen grains were collected for pollen analysis, only four of them (all Eg. stellfeldi) carried no pollen grains. With the exception of females collected in scent baits ( 15 El. seabrai females and one Eg. cordata) or captured in flight (a female of El. cingulata and one of El. seabrai), the other 46 samples were from females that visited flowers. Most of the material analysed was collected at Anchieta Island, which included 50 samples from six species (Ef. smaragdina, Eg. cordata, Eg. stellfeldi, El. cingulata, El. helvola, and El. seabrai); only 14 samples of four species (Ef. dentilabris, Ef. surinamensis, Eg. townsendi, and El. seabrai) were obtained from Picinguaba.

In total, 87 pollen types were identified belonging to 68 species from 24 families and 19 unidentified taxa. These 19 taxa were found in pollen samples from Ef. surinamensis (two taxa), Eg. cordata (four taxa), Eg. stellfeldi (two taxa), Eg. townsendi (one taxon), El. seabrai (12 taxa), El. helvola, and El. cingulata (one taxon each). Four of the unidentified taxa were found in pollen samples from eight bee species. Of the 15 plant species in which females were collected on flowers, only pollen grains of Alpinia zerumbet, Ipomoea tiliacea, and Temnadenia odorifera were not found in the samples, whereas pollen from Canistropsis seidelii, a species that was visited by 


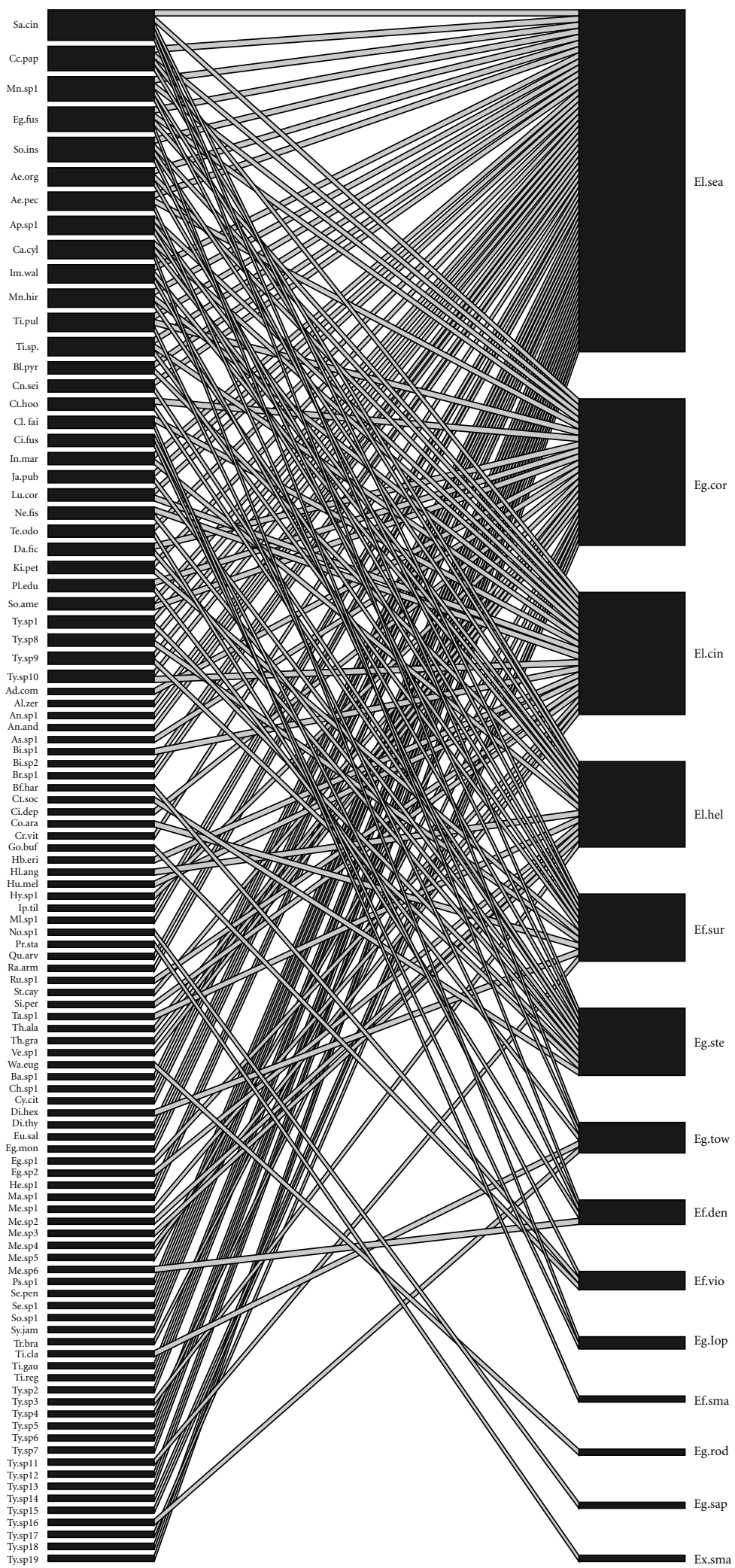

Figure 1: Network of interactions between plants and bees of the Euglossini tribe in two areas of the Atlantic Forest: Picinguaba and Anchieta Island, Ubatuba, SP. Bee species: El.sea—El. seabrai; Eg.cor-Eg. cordata; El.cin—El. cingulata; El.hev—El. helvola; Ef.sur-Ef. surinamensis; Eg.ste-Eg. stellfeldi; Eg.tow-Eg. townsendi; Ef.den-Ef. dentilabris; Ef.vio-Ef. violacea; Eg.iop-Eg. iopoecila; Ef.sma-Ef. smaragdina; Eg.rod-Eg. roderici; Eg.sap—Eg. sapphirina; Ex.sma-Ex. smaragdina. Plant species abbreviations are given at Table 3. 
TABLe 1: Plant species visited and flower resources collected by Euglossini bees around Ubatuba between August 2007 and July 2009.

\begin{tabular}{|c|c|c|c|}
\hline Families & Plant species & Resources & Areas \\
\hline Acanthaceae & Thunbergia alata Bojer ex Sims & Nectar & Anchieta Island \\
\hline \multirow{2}{*}{ Apocynaceae } & Mandevilla hirsuta (A.Rich.) K.Schum. & Nectar & Picinguaba \\
\hline & Temnadenia odorifera (Vell.) J.F.Morales & Nectar & Picinguaba \\
\hline Araceae & Anthurium andraeanum Linden & Fragrance & IO/USP \\
\hline Balsaminaceae & Impatiens walleriana Hook.f. & Nectar & Anchieta Island \\
\hline \multirow{2}{*}{ Bignoniaceae } & Adenocalymma comosum (Cham.) DC. & Nectar & Anchieta Island \\
\hline & Jacaranda puberula Cham. & Nectar & Picinguaba \\
\hline Bromeliaceae & Canistropsis seidelii (L.B.Smith and Reitz) Leme & Nectar & Picinguaba \\
\hline Caricaceae & Carica papaya L. & Nectar & Anchieta Island \\
\hline Commelinaceae & Dichorisandra hexandra (Aubl.) Kuntze ex Hand.-Mazz. & Pollen & Picinguaba \\
\hline Convolvulaceae & Ipomoea tiliacea (Willd.) Choisy & Nectar & Picinguaba \\
\hline Fabaceae & Clitoria fairchildiana R.A.Howard & Nectar & Anchieta Island \\
\hline \multirow{2}{*}{ Marantaceae } & Calathea cylindrica (Roscoe) K.Schum. & Nectar & Anchieta Island \\
\hline & Calathea monophylla (Vell.) Körn. & Nectar & Picinguaba \\
\hline \multirow{2}{*}{ Melastomataceae } & Tibouchina clavata (Pers.) Wurdack & Pollen & Picinguaba \\
\hline & Tibouchina regnellii Cogn. & Pollen & Picinguaba \\
\hline Pentaphylacaceae & Ternstroemia brasiliensis Cambess. & Pollen & Anchieta Island \\
\hline Rubiaceae & Sabicea cinerea Aubl. & Nectar & Picinguaba \\
\hline Solanaceae & Solanum insidiosum Mart. & Pollen & Anchieta Island \\
\hline Verbenaceae & Stachytarpheta cayennensis (Rich.) Vahl & Nectar & Anchieta Island \\
\hline Zingiberaceae & Alpinia zerumbet (Pers.) B.L.Burtt and R.M.Sm. & Nectar & Anchieta Island \\
\hline
\end{tabular}

Table 2: Species of Orchidaceae whose pollinaria were found attached to the bodies of male Euglossini collected in Picinguaba and Anchieta Island, Ubatuba, SP. P: Picinguaba, A: Anchieta Island.

\begin{tabular}{|c|c|c|c|}
\hline Orchids species & Euglossine species & Areas & $N=32^{*}$ \\
\hline Bifrenaria harrisoniae (Hook.) Rchb.f. & Ef. violacea $\left(1 \sigma^{\top}\right)$ & A & $1^{*}$ \\
\hline Catasetum hookeri Lindl. & Eg. cordata $\left(2 \sigma^{7}\right)$, Eg. stellfeldi $\left(7 \sigma^{7}\right)$ & $\mathrm{A}^{1}, \mathrm{P}^{2}$ & 9 \\
\hline Catasetum socco (Vell.) Hoehne & Eg. stellfeldi $\left(5 \sigma^{x}\right)$ & $\mathrm{A}^{3}, \mathrm{P}^{4}$ & 5 \\
\hline Cirrhaea dependens (Lodd.) Loudon & Eg. cordata $\left(110^{x}\right)$ & $\mathrm{A}^{5}, \mathrm{P}^{6}$ & 11 \\
\hline Cirrhaea fuscolutea Lindl. & Ef. violacea $\left(10^{7}\right)$, Eg. iopoecila $\left(2 \sigma^{7}\right)$ & $\mathrm{A}^{7}, \mathrm{P}^{8}$ & $3 *$ \\
\hline Gongora bufonia Lindl. & Ef. violacea $\left(1 \sigma^{\top}\right)$ & A & $1^{*}$ \\
\hline Huntleya meleagris Lindl. & El. cingulata $\left(10^{x}\right)$ & $\mathrm{P}$ & 1 \\
\hline Notylia sp. & Eg. sapphirina $\left(10^{7}\right)$ & $\mathrm{P}$ & 1 \\
\hline Promenaea stapelioides (Link. and Otto) Lindl. & Ex. smaragdina $\left(10^{\top}\right)$ & $\mathrm{P}$ & 1 \\
\hline Warmingia eugenii Rchb.f. & Eg. roderici $\left(10^{\top}\right)$ & $\mathrm{P}$ & 1 \\
\hline
\end{tabular}

* Only one individual of Ef. violacea was collected, which carried pollinaria of Bifrenaria harrisoniae, Cirrhaea fuscolutea, and Gongora bufonia.

${ }^{1} 5$ Eg. stellfeldi males and 1 Eg. cordata male, ${ }^{2} 2$ Eg. stellfeldi males and 1 Eg. cordata male, ${ }^{3} 2$ males, ${ }^{4} 3$ males, ${ }^{5} 1$ male, ${ }^{6} 10$ males, ${ }^{7} 1$ Ef. violacea male and 1 Eg. stellfeldi males, ${ }^{8} 2$ Eg. iopoecila males.

only one male of Eg. stellfeldi, was identified from the slides. Among all of the species of Euglossini, El. seabrai showed the greatest number of pollen types (51) followed by Eg. cordata (21) and El. cingulata (16).

Pollen was collected from 33 species represented by eight families: Myrtaceae $(N=9$ species $)$, Clusiaceae $(N=$ $1)$, Pentaphylacaceae $(N=1)$, Malpighiaceae $(N=3)$, Solanaceae $(N=3)$, Melastomataceae $(N=11)$, Fabaceae (subfamily Caesalpinioideae) $(N=3)$, and Commelinaceae $(N=2)$. Dalechampia ficifolia was the only source of resin identified in the samples from Eg. cordata and Eg. stellfeldi. The 34 species of plants identified as nectar sources were distributed among the families Acanthaceae $(N=2)$, Amaranthaceae $(N=1)$, Apocynaceae $(N=3)$, Asteraceae $(N=2)$, Balsaminaceae $(N=1)$, Bignoniaceae $(N=5)$, Bromeliaceae $(N=6)$, Caricaceae $(N=1)$, Costaceae 
TABLE 3: Abbreviated plant names used to construct the interactions are given. The 19 unidentified taxa were abbreviated as Ty. sp1, Ty. sp2, and so on.

\begin{tabular}{|c|c|}
\hline Families/species & Abbreviations \\
\hline \multicolumn{2}{|l|}{ Acanthaceae } \\
\hline Thunbergia alata Bojer ex Sims & Th.ala \\
\hline Thunbergia grandiflora Roxb. & Th.gra \\
\hline \multicolumn{2}{|l|}{ Amaranthaceae } \\
\hline Hebanthe eriantha (Poir.) Pedersen & Hb.eri \\
\hline \multicolumn{2}{|l|}{ Apocynaceae } \\
\hline Mandevilla hirsuta (A.Rich.) K.Schum. & Mn.hir \\
\hline Mandevilla sp.1 & Mn. sp1 \\
\hline Temnadenia odorifera (Vell.) J.F.Morales & Te.odo \\
\hline Type 1 & Ap. sp1 \\
\hline \multicolumn{2}{|l|}{ Araceae } \\
\hline Anthurium andraeanum Linden & An.and \\
\hline \multicolumn{2}{|l|}{ Asteraceae } \\
\hline Type 1 & As. sp 1 \\
\hline Vernonanthura sp.1 & Ve. $\mathrm{sp} 1$ \\
\hline \multicolumn{2}{|l|}{ Balsaminaceae } \\
\hline Impatiens walleriana Hook.f. & Im.wal \\
\hline \multicolumn{2}{|l|}{ Bignoniaceae } \\
\hline Adenocalymma comosum (Cham.) DC. & Ad.com \\
\hline Jacaranda puberula Cham. & Ja.pub \\
\hline Lundia cordata (Vell.) DC. & Lu.cor \\
\hline Stizophyllum perforatum (Cham.) Miers & Si.per \\
\hline Tabebuia sp.1 & Ta. sp1 \\
\hline Type 1 & Bi. sp1 \\
\hline Type 2 & Bi. sp2 \\
\hline \multicolumn{2}{|l|}{ Bromeliaceae } \\
\hline Aechmea organensis Wawra & Ae.org \\
\hline Aechmea pectinata Baker & Ae.pec \\
\hline Billbergia pyramidalis (Sims) Lindl. & Bl.pyr \\
\hline Canistropsis seidelii (L.B.Sm. and Reitz) Leme & Cn.sei \\
\hline Quesnelia arvensis (Vell.) Mez & Qu.arv \\
\hline Type 1 & Br.sp1 \\
\hline \multicolumn{2}{|l|}{ Caricaceae } \\
\hline Carica papaya L. & Cc.pap \\
\hline \multicolumn{2}{|l|}{ Clusiaceae } \\
\hline Kielmeyera petiolaris Mart. & Ki.pet \\
\hline \multicolumn{2}{|l|}{ Commelinaceae } \\
\hline $\begin{array}{l}\text { Dichorisandra hexandra (Aubl.) Kuntze ex } \\
\text { Hand.-Mazz. }\end{array}$ & Di.hex \\
\hline Dichorisandra thyrsiflora J.C.Mikan & Di.thy \\
\hline \multicolumn{2}{|l|}{ Convolvulaceae } \\
\hline Ipomoea tiliacea (Willd.) Choisy & Ip.til \\
\hline \multicolumn{2}{|l|}{ Costaceae } \\
\hline Costus arabicus $\mathrm{L}$. & Co.ara \\
\hline \multicolumn{2}{|l|}{ Euphorbiaceae } \\
\hline Dalechampia ficifolia Lam. & Da.fic \\
\hline \multicolumn{2}{|l|}{ Fabaceae } \\
\hline Andira sp. 1 & An. sp1 \\
\hline Clitoria fairchildiana R.A.Howard & Cl.fai \\
\hline Crotalaria vitellina Ker Gawl. & Cr.vit \\
\hline
\end{tabular}

Table 3: Continued.

\begin{tabular}{|c|c|}
\hline Families/species & Abbreviations \\
\hline Inga marginata Willd. & In.mar \\
\hline $\begin{array}{l}\text { Senna pendula (Humb. and Bonpl. ex Willd.) } \\
\text { H.S.Irwin and Barneby }\end{array}$ & Se.pen \\
\hline Senna sp.1 & Se. sp1 \\
\hline Type Chamaecrista & Ch. sp1 \\
\hline \multicolumn{2}{|l|}{ Gesneriaceae } \\
\hline Nematanthus fissus (Vell.) L.E.Skog & Ne.fis \\
\hline \multicolumn{2}{|l|}{ Heliconiaceae } \\
\hline Heliconia angusta Vell. & Hl.ang \\
\hline \multicolumn{2}{|l|}{ Lamiaceae } \\
\hline Hyptis sp. 1 & Hy. sp1 \\
\hline \multicolumn{2}{|l|}{ Malpighiaceae } \\
\hline Heteropterys sp.1 & He. sp 1 \\
\hline Type Banisteriopsis & Ba. sp1 \\
\hline Type 1 & Ma. sp1 \\
\hline \multicolumn{2}{|l|}{ Malvaceae } \\
\hline Type 1 & Ml. sp1 \\
\hline \multicolumn{2}{|l|}{ Marantaceae } \\
\hline Calathea cylindrica (Roscoe) K.Schum. & Ca.cyl \\
\hline Calathea monophylla (Vell.) Körn. & Ca.mon \\
\hline \multicolumn{2}{|l|}{ Melastomataceae } \\
\hline Tibouchina clavata (Pers.) Wurdack & Ti.cla \\
\hline Tibouchina gaudichaudiana (DC.) Baill. & Ti.gau \\
\hline Tibouchina cf. pulchra Cogn. & Ti.pul \\
\hline Tibouchina regnellii Cogn. & Ti.reg \\
\hline Tibouchina sp.1 & Ti. sp1 \\
\hline Type 1 & Me. sp1 \\
\hline Type 2 & Me. sp2 \\
\hline Type 3 & Me. sp3 \\
\hline Type 4 & Me. sp4 \\
\hline Type 5 & Me. sp5 \\
\hline Type 6 & Me. sp6 \\
\hline \multicolumn{2}{|l|}{ Myrtaceae } \\
\hline $\begin{array}{l}\text { Corymbia citriodora (Hook.) K.D.Hill and } \\
\text { L.A.S.Johnson }\end{array}$ & Cy.cit \\
\hline Eucalyptus saligna Sm. & Eu.sal \\
\hline Eugenia cf. fusca O.Berg & Eg.fus \\
\hline Eugenia cf. monosperma Vell. & Eg.mon \\
\hline Eugenia sp.1 & Eg. sp1 \\
\hline Eugenia sp.2 & Eg. sp2 \\
\hline Plinia edulis (Vell.) Sobral & Pl.edu \\
\hline Psidium sp.1 & Ps. sp1 \\
\hline Syzygium jambos (L.) Alston & Sy.jam \\
\hline \multicolumn{2}{|l|}{ Orchidaceae } \\
\hline Huntleya meleagris Lindl. & Hu.mel \\
\hline Notylia sp. & No. sp1 \\
\hline Promenaea stapelioides (Link. and Otto) Lindl. & Pr.sta \\
\hline Warmingia eugenii Rchb.f. & Wa.eug \\
\hline
\end{tabular}


TABle 3: Continued.

\begin{tabular}{lc}
\hline Families/species & Abbreviations \\
\hline Pentaphylacaceae & \\
$\quad$ Ternstroemia brasiliensis Cambess. & Tr.bra \\
Rubiaceae & \\
$\quad$ Randia armata (Sw.) DC. & Ra.arm \\
Sabicea cinerea Aubl. & Sa.cin \\
Type 1 & Ru. sp1 \\
Solanaceae & \\
$\quad$ Solanum americanum Mill. & So.ame \\
Solanum insidiosum Mart. & So.ins \\
Solanum sp.1 & So. sp1 \\
Verbenaceae & \\
Stachytarpheta cayennensis (Rich.) Vahl & St.cay \\
Zingiberaceae & \\
$\quad$ Alpinia zerumbet (Pers.) B.L.Burtt and & Al.zer \\
R.M.Sm.
\end{tabular}

$(N=1)$, Fabaceae (subfamilies Mimosoideae $(N=1)$ and Faboideae $(N=3))$, Gesneriaceae $(N=1)$, Heliconiaceae $(N=1)$, Lamiaceae $(N=1)$, Malvaceae $(N=1)$, Rubiaceae $(N=3)$, and Verbenaceae $(N=1)$.

Samples of pollen removed from females from Anchieta Island revealed the presence of exotic species such as Thunbergia alata, Thunbergia grandiflora, Corymbia citriodora, and Eucalyptus saligna, as well as Impatiens walleriana and Carica papaya, which were exploited as sources of nectar.

3.4. Interaction Networks. A total of 153 qualitative interactions between 105 species of plants and 14 Euglossini species were identified in the present study. The interaction network was nested (NODF 15.46, $P>0.05$ ), the network connectance was relatively high (0.106), with the asymmetry of the interaction network evident in the bipartite graphical representation (Figure 1), where a few species had many interactions and many species were attributed with a single interaction. Generally, plants had few interactions, with Sabicea cinerea connected to five Euglossini species and Carica papaya, Mandevilla sp., Eugenia cf. fusca, and Solanum insidiosum to four species. Seventy-two plant species showed only one network interaction. Bees, on the other hand, showed a much higher number of interactions, with $E l$. seabrai being connected to 55 plant species, representing $35 \%$ of interactions. Euglossa cordata and El. cingulata also stood out in their numbers of interactions with 24 and 20 interactions, respectively. Eufriesea smaragdina, Eg. roderici, Eg. sapphirina, and Ex. smaragdina showed only a single network interaction each. All of the types of resources offered by plants to male and female Euglossini are included in the interactions described.

Most of the observed interactions were based on two types of resources, pollen and nectar, which were responsible for $46 \%$ and $45 \%$ of interactions, respectively. Fragrance resources were responsible for $8 \%$ of the interactions, and resin contributed to only $1 \%$ of the total interactions.
Only three instances were recorded of males and females sharing the same plant species in search of the same type of resource, nectar. These instances were Eg. stellfeldi $\mathrm{x}$ Impatiens walleriana, El. seabrai $\mathrm{x}$ Impatiens walleriana, and El. cingulata x Clitoria fairchildiana.

The interaction networks grouped by nectar (Figure 2) was also nested (NODF 23.24, $P>0.05$ ), whereas the pollen network (Figure 3 ) was not significantly nested (NODF $22.36, P=0.38$ ). Analyzing the interactions of bees with the type of resource, nectar and pollen, offered by the plants, it is possible to observe alternation in plant species that offer each type of resource, and in both cases there is a marked predominance of one plant species. Regarding bees it is possible to observe in both types of floral resources the dominance of some bee species by the offered resource. The species El. seabrai interacted with the largest number of nectar resources (22), followed by El. cingulata (12) and Eg. cordata (11) (Figure 2). The bee species that had the highest number of interactions with plants that provide pollen as floral rewards were $E f$. dentilabris (21), Ef. surinamensis (6) and, Eg. cordata (6).

\section{Discussion}

As reported for other Euglossini species [35, 39, 43, 44, 57, 58], the species sampled in Ubatuba can also be characterised as polylectic. This conclusion is supported not only by the records of male and female bees on flowers but also the analysis of pollen loads from the corbiculae and other parts of the bodies of females, from which more than 100 plant species exploited as sources of pollen, nectar, resin, and floral fragrances were identified.

Results from the present study support findings from previous studies that report that species of plants from the Solanaceae, Fabaceae, and Melastomaceae families are among the most important sources of pollen for Euglossini species $[44,57-60]$. This information strongly suggests that Euglossini females exhibit certain consistency in collecting pollen, particularly from species whose flowers have poricidal anthers. According to Roulston et al. [61], the protein content of pollen from these plants can reach up to $48 \%$, a substantial value that lies within the range of the percentage of protein, $12-61 \%$, found in grains of pollen usually collected by bees.

In addition to species of the families Solanaceae, Fabaceae, and Melastomaceae, Myrtaceae species are also visited to obtain pollen, as observed in the present study and reported by Bittrich et al. [62] for Euglossa sp., by TorezanSilingardi and Del-Claro [63] for El. nigrita, and Falcão et al. [64] for Eulaema mocsaryi (Friese, 1899). Euglossini bees pollinate species lacking anthers with poricidal dehiscence through a process of vibrating the anthers, known as "buzzpollination." The Euglossini are also important pollinators of species of Kielmeyera Mart. \& Zucc. (Guttiferae) [65, 66], which, like the Myrtaceae, also have flowers with numerous stamens and longitudinal anthers. "Buzz-pollination" behaviour allows for a smaller number of visits by bees to these flowers in addition to being a more efficient method 


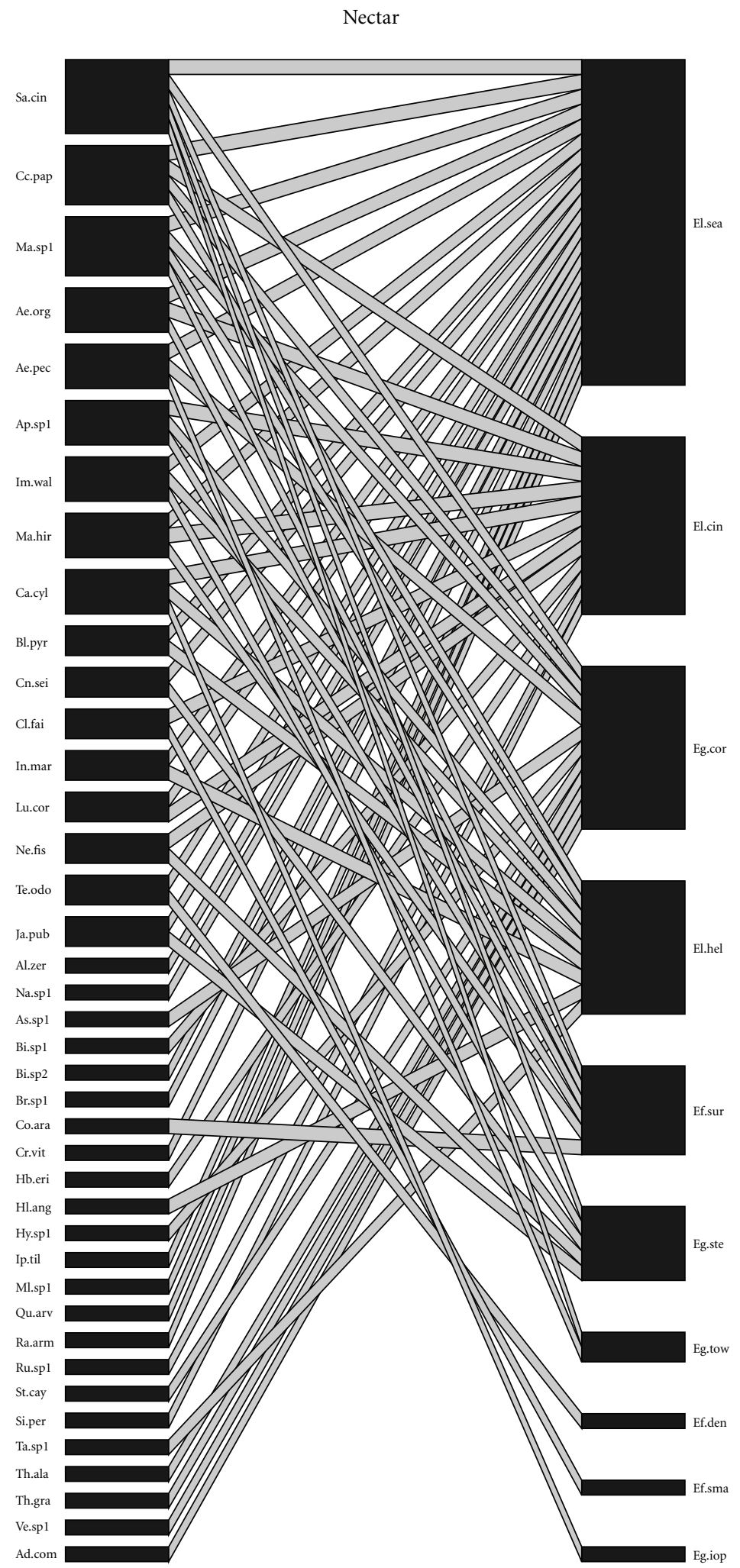

FIGURE 2: Interaction networks between plants and bees of the Euglossini tribe, grouped by the nectar resources that were exploited both by females and males in two areas of Atlantic Forest, Picinguaba and Anchieta Island, Ubatuba, SP. Bee species: El.sea—El. seabrai; El.cinEl. cingulata; Eg.cor—Eg. cordata; El.hev—El. helvola; Ef.sur-Ef. surinamensis; Eg.ste—Eg. stellfeldi; Eg.tow—Eg. townsendi; Ef.den—Ef. dentilabris; Ef.sma-Ef. smaragdina; Eg.iop_Eg. iopoecila. Plant species abbreviations are given at Table 3. 


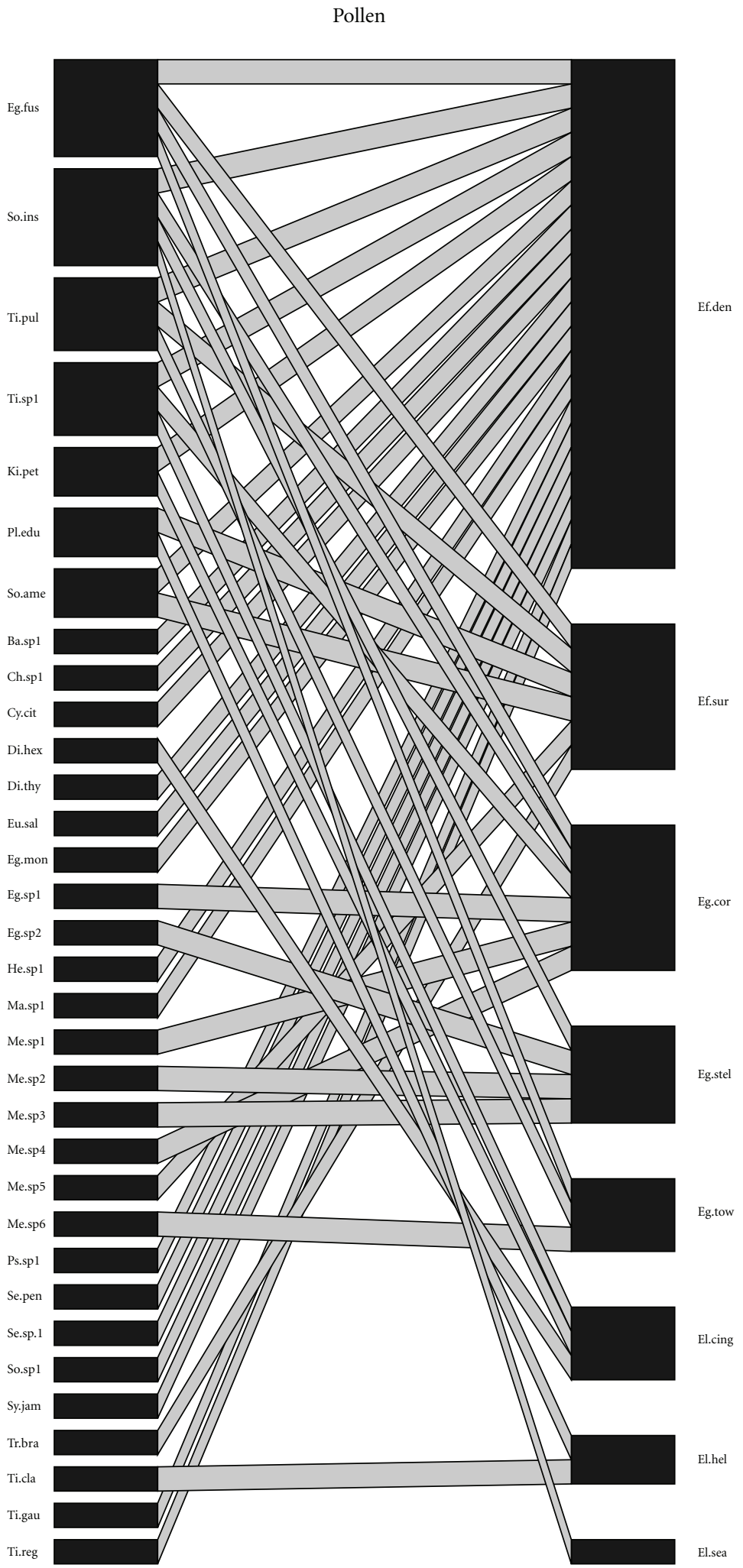

FIGURE 3: Interaction networks between plants and bees from the Euglossini tribe, grouped by the pollen resources that were exploited solely by females in two areas of Atlantic Forest: Picinguaba and Anchieta Island, Ubatuba, SP. Bee species: Ef.den-Ef. dentilabris; Ef.sur-Ef. surinamensis; Eg.cor—Eg. cordata; Eg.ste-Eg. stellfeldi; Eg.tow_Eg. townsendi; El.cin—El. cingulata; El.hev-El. helvola; El.sea-El. seabrai. Plant species abbreviations are given at Table 3. 
to obtain pollen, as a greater number of stamens are joined and more anthers are vibrated at once [65]. According to Buchmann [36], there are rare cases where the pollen is collected through sonication in flowers with anthers lacking poricidal openings; there are, as yet, no definite causes for this, which could also be a "side effect" of the behaviour of the bees.

Although the stems of some species, such as Protium Burm.f. (Burseraceae), Anacardium L., and Spondias L. (Anacardiaceae), can be scraped by Euglossini females to obtain resin [4, 57], species of Clusia L. (Clusiaceae) are also visited for the collection of that resource, which is used in the construction of nests and brood cells [67, 68]. However, Dalechampia flowers (Euphorbiaceae) are most commonly cited as major sources of resin for diverse species of Eufriesea, Euglossa, and Eulaema [20, 38, 44, 58, 69, 70]. In the present study, the only identified source of resin was a species of the genus Dalechampia, showing, once again, the association of Euglossini species with a species of that genus.

Analysing the pollinaria present in males collected at Picinguaba, Singer, and Sazima [71] identified 11 species of orchids belonging to nine genera. This result is similar to that shown in the present study, in which the pollinaria of ten species of Orchidaceae from eight genera were obtained. The data of the present study added to the information obtained from the region of Picinguaba by Singer and Sazima [71, 72], Pansarin et al. [73], and Pansarin and Amaral [74] increase the total numbers of Euglossini species and orchid species present in that area to 15 and 14, respectively. Only $2.13 \%$ of the 1503 males collected in Ubatuba for the present study showed evidence of association with orchids. Similarly, in the south of Minas Gerais State, Peruquetti et al. [45] found pollinaria attached to males in only $0.58 \%$ of individuals collected. These low percentages of males carrying pollinaria corroborate the observations of Ackerman [22] that such an occurrence is very uncommon in the males collected in surveys.

Although orchids are the primary sources of floral fragrances used by Euglossini males, plants of other families are also visited to obtain this resource, such as Anthurium andraeanum, from which males of El. seabrai were collected. Sazima et al. [75], also in Ubatuba, observed males of Euglossa mandibularis Friese, 1899 collecting fragrances in the flowers of Solanum diploconos (cited as Cyphomandra diploconos), and Soares et al. [23] recorded males of the same species in Solanum latiflorum Bohs (cited as Cyphomandra calycina) in Minas Gerais. Gracie [76] observed that male Eufriesea convexa (Friese, 1899) and Eufriesea elegans (Lepeletier, 1841) visited the flowers of Solanum endopogon (Bitter) Bohs (cited as Cyphomandra endopogon var. endopogon) to collect aromatic compounds. Not only the flowers but also leaves, fruits, sap, fungi that grow on rotting logs, mushrooms, and terrestrial bird droppings are also sources of aromatic compounds exploited by males [16, 77]. This information, together with the low numbers of pollinaria found in males collected in artificial baits [22], has led some authors [35, 39, 78] to question the mutualism between male Euglossini and orchids. Pemberton and Wheeler [79] showed that males of a species introduced in Florida, Euglossa viridissima Friese, 1899 did not depend on orchids, as they collected aromatic oils in the leaves of cultivated species such as basil, Ocimum basilicum L. (Lamiaceae), and allspice, Pimenta dioica (L.) (Myrtaceae).

The collection of floral resources from exotic plants on Anchieta Island could be a reflection of the long history of human intervention on the island, which resulted in the degradation of forest areas and the introduction of plant species of economic interest such as coconut, Cocos nucifera L. (Arecaceae), coffee, Coffea arabica L. (Rubiaceae), and sugar cane, Saccharum officinarum L. (Poaceae), which were cultivated during the period when the Correctional Colony was active [49].

The network formed by oil-producing flowers (Malpighiaceae) and their pollinating bees was considered by Bezerra et al. [48] as a "tiny world" within another small world of pollination networks. In the present study, the "small world" would be the study of plants visited by Euglossini bees. The connectance found in the present study was superior to large networks $[80,81]$ and very similar to that found in relatively small networks [82, 83]; Biesmeijer et al. [84] showed a large variation $(7.2 \%$ to $37.1 \%)$ in the connectance of 27 networks of social bees and their plants.

The asymmetry of the interactions in the present study, whereby a few species have many interactions and many species have few interactions in the network, was also found by Vázquez and Aizen [85] as a trait of the system. However Bascompte et al. [86] propose that community coexistence is supported by the architecture of quantitative mutualistic networks which is characterized by the low number of strong dependences, their asymmetry, and the high heterogeneity in species strength. However, Stang et al. [87] noted that the availability of floral resources may direct interactions in a community where the population density and the amount of available flowers are also responsible for structuring the network of interactions.

The Euglossini species explored an impressive diversity of nectar sources in Ubatuba, especially plants with long, tubular corolla flowers. Flowers with corolla of this kind, which have a light colouring and produce nectar in large quantities with difficult access for floral visitors, may be classified as euglossophilous, that is, plants that have characteristics of a pollination syndrome called euglossophily [88]. Euglossini are endowed with elongated glossa and can therefore utilise a wide range of flowers, even those that have a long and narrow corolla, which are only accessible to other bees if they pierce the base, acting as robbers that are unable to pollinate the plant [35]. Roubik et al. [89] noted that Euglossini bees visit flowers that produce nectar with a high concentration of sugars to satisfy their physiological needs, because when they are active, their body temperature becomes high, requiring a high energy diet [90]. In addition to euglossophilous plants, flowers lacking tubular corolla, such as species of Fabaceae, Amaranthaceae, Lamiaceae, and Malvaceae, were also visited by bees in Ubatuba, which highlights the broad spectrum of plant species that are exploited by the Euglossini 
bees.

These bees are one of the most important groups of pollinators in tropical regions, not only due to interactions with different plants that produce pollen, nectar, resin, and floral fragrances but also for their role as pollinators with a wide flight radius that are able to support the reproductive biology of plants that are scattered and have low densities $[11,35]$. By achieving greater diversity in tropical rain forests, which is the type of ecosystem that suffers most from the fragmentation of habitats, deforestation, and human actions [91], the Euglossini become especially vulnerable to these processes [39], which makes conservation and management essential for the preservation of these bees and their floral resources.

\section{Acknowledgments}

This study was supported by "Conselho Nacional de Desenvolvimento Científico e Tecnológico" (CNPq; Grant no. 141022/2007-8) to L. C. da Rocha Filho and the "Fundação de Amparo à Pesquisa do Estado de São Paulo" (FAPESP; Grant no. 04/15801-0) which has financed some of our collection trips. The authors also thank the taxonomists who have identified some of the plant species: A.F. NunesFreitas-UFRRJ (Canistropsis seidelii), D.C. Maia (Dichorisandra hexandra), I. Koch-UFSCar (Mandevilla hirsuta and Temnadenia odorifera), L.G. Lohmann-USP (Adenocalymma comosum), M.A.P. Accardo-Filho (Ternstroemia brasiliensis), M.F. Agra-UFPB (Sabicea cinerea and Solanum insidiosum), R. Romero-UFU (Tibouchina clavata and T. regnellii), R. Simão-Bianchini-IBOT (Ipomoea tiliacea), R. Singer-UFRGS (Orchidaceae pollinaria), V.L.R. Uliana (Calathea monophylla), and the staff at the study sites (PESM and PEIA) for their support.

\section{References}

[1] R. L. Dressler, "Pollination by euglossine bees," Evolution, vol. 22, no. 1, pp. 202-210, 1968.

[2] N. H. Williams, "The biology of orchids and euglossine bees," in Orchid Biology: Reviews and Perspectives II, J. Arditti, Ed., pp. 119-171, Cornell University Press, Ithaca, NY, USA, 1982.

[3] C. Schlindwein, "A importância de abelhas especializadas na polinização de plantas nativas e conservação do meio ambiente," Anais do Encontro sobre Abelhas, vol. 4, pp. 131141,2000

[4] R. Zucchi, S. F. Sakagami, and J. M. F. Camargo, "Biological observations on a neotropical parasocial bee, Eulaema nigrita, with a review on the biology of Euglossinae (Hymenoptera: Apidae). A comparative study," Journal of Faculty of Science of Hokkaido University, vol. 17, no. 2, pp. 271-380, 1969.

[5] C. A. Garófalo, "Social structure of Euglossa cordata nests (Hymenoptera, Apidae, Euglossini)," Entomologia Generalis, vol. 11, no. 1-2, pp. 77-83, 1985.

[6] C. A. Garófalo, "Comportamento de nidificação e estrutura de ninhos de Euglossa cordata (Hymenoptera: Apidae: Euglossini)," Revista Brasileira de Biologia, vol. 52, no. 1, pp. 187-198, 1992.
[7] M. L. Santos and C. A. Garofalo, "Nesting biology and nest reuse of Eulaema nigrita (Hymenoptera: Apidae, Euglossini)," Insectes Sociaux, vol. 41, no. 1, pp. 99-110, 1994.

[8] C. A. Garófalo, E. Camillo, S. C. Augusto, B. M. V. Jesus, and J. C. Serrano, "Nest structure and communal nesting in Euglossa (Glossura) annectans Dressler (Hymenoptera, Apidae, Euglossini)," Revista Brasileira de Zoologia, vol. 15, no. 3, pp. 589-596, 1998.

[9] S. C. Augusto and C. A. Garófalo, "Nesting biology and social structure of Euglossa (Euglossa) townsendi Cockerell (Hymenoptera, Apidae, Euglossini)," Insectes Sociaux, vol. 51, no. 4, pp. 400-409, 2004.

[10] S. C. Augusto and C. A. Garófalo, "Bionomics and sociological aspects of Euglossa fimbriata (Apidae, Euglossini)," Genetics and Molecular Research, vol. 8, no. 2, pp. 525-538, 2009.

[11] D. H. Janzen, "Euglossine bees as long-distance pollinators of tropical plants," Science, vol. 171, no. 3967, pp. 203-205, 1971.

[12] D. E. Kroodsma, "Flight distances of male euglossine bees in orchid pollination," Biotropica, vol. 7, no. 1, pp. 71-72, 1975.

[13] M. Wikelski, J. Moxley, A. Eaton-Mordas et al., "Large-range movements of neotropical orchid bees observed via radio telemetry," PLoS ONE, vol. 5, no. 5, Article ID e10738, 2010.

[14] L. Pijl and C. H. Dodson, Orchid Flowers: Their Pollination and Evolution, University of Miami Press, Coral Gables, Fla, USA, 1966.

[15] J. D. Ackerman, "Diversity and seasonality of male euglossine bees (Hymenoptera: Apidae) in central Panama," Ecology, vol. 64, no. 2, pp. 274-283, 1983.

[16] N. H. Williams and W. M. Whitten, "Orchid floral fragrances and male euglossine bees. Methods and advances in the last sesquidecade," Biological Bulletin, vol. 164, no. 3, pp. 355-395, 1983.

[17] C. J. Murren, "Effects of habitat fragmentation on pollination: pollinators, pollinia viability and reproductive success," Journal of Ecology, vol. 90, no. 1, pp. 100-107, 2002.

[18] S. Vogel, "Parfümsammelnde bienen als bestäuber von orchidaceen und Gloxinia," Österreichische Botanische Zeitschrift, vol. 113, no. 3-4, pp. 302-361, 1966.

[19] N. H. Williams and R. L. Dressler, "Euglossine pollination of Spathiphyllum (Araceae)," Selbyana, vol. 1, no. 4, pp. 349-356, 1976.

[20] W. S. Armbruster and G. Webster, "Pollination of two species of Dalechampia (Euphorbiaceae) in Mexico by euglossine bees," Biotropica, vol. 11, no. 4, pp. 278-283, 1979.

[21] S. L. Buchmann, "Preliminary anthecological observations on Xiphidium caeruleum Aubl. (Monocotyledonae: Haemodoraceae) in Panama," Journal of the Kansas Entomological Society, vol. 53, no. 4, pp. 685-699, 1981.

[22] J. D. Ackerman, "Specificity and mutual dependency of the orchid-euglossine bee interaction," Biological Journal of the Linnean Society, vol. 20, no. 3, pp. 301-314, 1983.

[23] A. A. Soares, L. A. O. Campos, M. F. Vieira, and G. A. R. Melo, "Relações entre Euglossa (Euglossella) mandibularis Friese, 1899 (Hymenoptera, Apidae, Euglossini) e Cyphomandra calycina (Solanaceae)," Ciência e Cultura, vol. 41, no. 9, pp. 903-905, 1989.

[24] G. A. Melo, "Fragrance gathering by Euglossa males in flowers of Ternstroemia dentata (Theaceae) (Hymenoptera: Apidae: Euglossinae)," Entomologia Generalis, vol. 19, no. 4, pp. 281283, 1995.

[25] J. T. Knudsen and S. A. Mod, "Floral scents and pollination in neotropical lecythidaceae," Biotropica, vol. 28, no. 1, pp. $42-$ 60, 1996. 
[26] P. C. D. L. Nogueira, A. J. Marsaioli, M. D. C. E. Amaral, and V. Bittrich, "The fragrant floral oils of Tovomita species," Phytochemistry, vol. 49, no. 4, pp. 1009-1012, 1998.

[27] A. K. Braga and C. A. Garófalo, "Coleta de fragrâncias por machos de Euglossa townsendi Cockerell (Hymenoptera, Apidae, Euglossini) em flores de Crinum procerum Carey (Amaryllidaceae)," in Apoidea Neotropica: Homenagem aos 90 Anos de Jesus Santiago Moure, G. A. R. Melo and I. Alves-dosSantos, Eds., pp. 201-207, UNESC, Criciúma, Brazil, 2003.

[28] J. A. Siqueira-Filho and I. C. Machado, "Flowering phenology and pollination ecology of Cryptanthus dianae Leme: a case of flower fragrance-collecting by Euglossinae bees in Bromeliaceae," Selbyana, vol. 29, no. 2, pp. 226-232, 2008.

[29] H. Teichert, S. Dötterl, B. Zimma, M. Ayasse, and G. Gottsberger, "Perfume-collecting male euglossine bees as pollinators of a basal angiosperm: the case of Unonopsis stipitata (Annonaceae)," Plant Biology, vol. 11, no. 1, pp. 2937, 2009.

[30] S. C. Cappellari, B. Harter-Marques, P. Aumeier, and W. Engels, "Mecardonia tenella (Plantaginaceae) Attracts Oil-, Perfume-, and Pollen-Gathering Bees in Southern Brazil," Biotropica, vol. 41, no. 6, pp. 721-729, 2009.

[31] C. H. Dodson and C. P. Frymire, "Preliminary studies in the genus Stanhopea," Annals of the Missouri Botanical Garden, vol. 48, no. 2, pp. 137-172, 1961.

[32] C. Cruz-Landim, A. C. Stort, M. A. Costa-Cruz, and E. W. Katajima, "Órgão tibial dos machos de Euglossini: estudo ao microscópio óptico e electrônico," Revista Brasileira de Biologia, vol. 25, no. 4, pp. 323-341, 1965.

[33] T. Eltz, A. Sager, and K. Lunau, "Juggling with volatiles: exposure of perfumes by displaying male orchid bees," Journal of Comparative Physiology A, vol. 191, no. 7, pp. 575-581, 2005.

[34] Y. Zimmermann, D. W. Roubik, and T. Eltz, "Speciesspecific attraction to pheromonal analogues in orchid bees," Behavioral Ecology and Sociobiology, vol. 60, no. 6, pp. 833$843,2006$.

[35] R. L. Dressler, "Biology of the orchid bees (Euglossini)," Annual Review of Ecology and Systematics, vol. 13, pp. 373-394, 1982.

[36] S. L. Buchmann, "Buzz pollination in angiosperms," in Handbook of Experimental Pollination Biology, C. J. Jones and R. J. Little, Eds., pp. 73-114, Nostrand \& Reinhold, New York, NY, USA, 1983.

[37] W. S. Armbruster, "The role of resin in angiosperm pollination: ecological and chemical considerations," American Journal of Botany, vol. 71, no. 8, pp. 1149-1160, 1984.

[38] M. Sazima, I. Sazima, and R. M. Carvalho-Okano, "Biologia floral de Dalechampia stipulacea (Euphorbiaceae) e sua polinização por Euglossa melanotricha (Apidae)," Revista Brasileira de Biologia, vol. 45, no. 1-2, pp. 85-93, 1985.

[39] D. W. Roubik and P. E. Hanson, Orchid Bees of Tropical America: Biology and Field Guide, Instituto Nacional de Biodiversidad, Santo Domingo de Heredia, Costa Rica, 2004.

[40] P. Milet-Pinheiro and C. Schlindwein, "Pollination in Jacaranda rugosa (Bignoniaceae): Euglossine pollinators, nectar robbers and low fruit set," Plant Biology, vol. 11, no. 2, pp. 131-141, 2009.

[41] J. D. Ackerman, "Euglossine bees and their nectar hosts," in The Botany and Natural History of Panama, W. G. D'Arcy and A. M. D. Correa, Eds., pp. 225-233, Missouri Botanical Garden, Saint Louis, Mo, USA, 1985.
[42] S. R. Ramírez, R. L. Dressler, and M. Ospina, "Abejas euglosinas (Hymenoptera: Apidae) de la región Neotropical: Listado de especies con notas sobre su biología," Biota Colombiana, vol. 3, no. 1, pp. 7-118, 2002.

[43] D. W. Roubik and J. E. Moreno, Pollen and Spores of Barro Colorado Island, Missouri Botanical Garden, New York, NY, US, 1991.

[44] E. R. Arriaga and E. M. Hernández, "Resources foraged by Euglossa atroveneta (Apidae: Euglossinae) at Union Juarez, Chiapas, Mexico. A palynological study of larval feeding," Apidologie, vol. 29, no. 4, pp. 347-359, 1998.

[45] R. C. Peruquetti, L. A. O. Campos, C. D. P. Coelho, C. V. M. Abrantes, and L. C. O. Lisboa, "Abelhas Euglossini (Apidae) de áreas de Mata Atlântica: abundância, riqueza e aspectos biológicos," Revista Brasileira de Zoologia, vol. 16, no. 2, pp. 101-118, 1999.

[46] J. Memmott, "The structure of a plant-pollinator food web," Ecology Letters, vol. 2, no. 5, pp. 276-280, 1999.

[47] D. P. Vázquez, N. Blüthgen, L. Cagnolo, and N. P. Chacoff, "Uniting pattern and process in plant-animal mutualistic networks: a review," Annals of Botany, vol. 103, no. 9, pp. 14451457, 2009.

[48] E. L. S. Bezerra, I. C. MacHado, and M. A. R. Mello, "Pollination networks of oil-flowers: a tiny world within the smallest of all worlds," Journal of Animal Ecology, vol. 78, no. 5, pp. 10961101, 2009.

[49] J. R. Guillaumon, M. A. P. Marcondes, O. C. Negreiros et al., Plano de Manejo do Parque Estadual da Ilha Anchieta. I.F.Série Registros, Instituto Florestal, São Paulo, Brazil, 1989.

[50] C. Rizzini, Tratado de Fitogeografia do Brasil, Âmbito Cultural, Rio de Janeiro, Brazil, 2nd edition, 1977.

[51] D. F. Peralta, Musgos (Bryophyta) do Parque Estadual da Itha Anchieta (PEIA) [M.S. thesis], Instituto de Botânica de São Paulo, São Paulo, Brazil, 2005.

[52] G. Erdtman, Handbook of Palynology: Morphology, Taxonomy, Ecology: An Introduction to the Study of Pollen Grains and Spores, Hafner Publishing Company, New York, NY, US, 1969.

[53] SpeciesLink, 2009, http://splink.cria.org.br.

[54] J. P. R. Guimaraes and P. Guimarães, "Improving the analyses of nestedness for large sets of matrices," Environmental Modelling and Software, vol. 21, no. 10, pp. 1512-1513, 2006.

[55] C. F. Dormann, B. Gruber, and J. Fründ, "Introducing the bipartite package: analysing ecological networks," R News, vol. 8, no. 2, pp. 8-11, 2008.

[56] L. C. Rocha-Filho and C. A. Garófalo, "Community ecology of euglossine bees (Hymenoptera, Apidae) in the coastal Atlantic Forest of Sao Paulo State, Brazil," Journal of Insect Science. In press.

[57] C. H. Dodson, "Ethology of some bees of the tribe Euglossini (Hymenoptera: Apidae)," Journal of the Kansas Entomological Society, vol. 39, no. 4, pp. 607-629, 1966.

[58] M. Cortopassi-Laurino, A. Zillikens, and J. Steiner, "Pollen sources of the orchid bee Euglossa annectans Dressler 1982 (Hymenoptera: Apidae, Euglossini) analyzed from larval provisions," Genetics and Molecular Research, vol. 8, no. 2, pp. 546-556, 2009.

[59] B. F. Viana, A. M. P. Kleinert, and E. L. Neves, "Comunidade de Euglossini (Hymenoptera, Apidae) das dunas litorâneas do Abaeté, Salvador, Bahia, Brasil," Revista Brasileira de Entomologia, vol. 46, no. 4, pp. 539-545, 2002.

[60] C. I. Silva, N. G. Bordon, L. C. Rocha-Filho, and C. A. Garofalo, "The importance of plant diversity in maintaining 
the pollinator bee, Eulaema nigrita (Hymenoptera: Apidae) in sweet passion fruit fields," Revista de Biologia Tropical, vol. 60, no. 4 , pp. $1553-1565$.

[61] T. H. Roulston, J. H. Cane, and S. L. Buchmann, "What governs protein content of pollen: Pollinator preferences, pollenpistil interactions, or phylogeny?” Ecological Monographs, vol. 70, no. 4, pp. 617-643, 2000.

[62] V. Bittrich, M. C. E. Amaral, and G. A. R. Melo, "Pollination biology of Ternstroemia laevigata and T. dentata (Theaceae)," Plant Systematics and Evolution, vol. 185, no. 1-2, pp. 1-6, 1993.

[63] H. M. Torezan-Silingardi and K. Del-Claro, "Behavior of visitors and reproductive biology of Campomanesia pubescens (Myrtaceae) in cerrado vegetation," Ciência e Cultura, vol. 50, no. 4, pp. 282-284, 1998.

[64] M. A. Falcão, R. M. S. Galvão, C. R. Clement, S. A. N. Ferreira, and S. G. Sampaio, "Fenologia e produtividade do araçá-boi (Eugenia stipitata, Myrtaceae) na Amazônia Central," Acta Amazonica, vol. 30, no. 1, pp. 9-21, 2000.

[65] P. E. A. M. de Oliveira and M. Sazima, "Pollination biology of two species of Kielmeyera (Guttiferae) from Brazilian cerrado vegetation," Plant Systematics and Evolution, vol. 172, no. 1-4, pp. 35-49, 1990.

[66] M. A. G. Barros, "Floração sincrônica e sistemas reprodutivos em quatro espécies de Kielmeyera Mart. (Guttiferae)," Acta Botanica Brasilica, vol. 16, no. 1, pp. 113-122, 2002.

[67] A. V. Lopes and I. C. Machado, "Floral biology and reproductive ecology of Clusia nemorosa (Clusiaceae) in northeastern Brazil," Plant Systematics and Evolution, vol. 213, no. 1-2, pp. 71-90, 1998.

[68] A. C. Kaminski and M. L. Absy, "Bees visitors of three species of Clusia (Clusiaceae) flowers in Central Amazonia," Acta Amazonica, vol. 36, no. 2, pp. 259-263, 2006.

[69] W. S. Armbruster and A. L. Herzig, "Partitioning and sharing of pollinators by four sympatric species of Dalechampia (Euphorbiaceae) in Panama," Annals of the Missouri Botanical Garden, vol. 71, no. 1, pp. 1-16, 1984.

[70] W. S. Armbruster, "Evolution of plant pollination systems: hypotheses and tests with the neotropical vine Dalechampia," Evolution, vol. 47, no. 5, pp. 1480-1505, 1993.

[71] R. B. Singer and M. Sazima, "Abelhas Euglossini como polinizadoras de orquídeas na região de Picinguaba, São Paulo, Brasil," in Orquidologia Sul-Americana: Uma Compilação Científica, F. Barros and G. B. Kerbauy, Eds., pp. 175-187, Centro de Editoração da Secretaria do Meio Ambiente do Estado de São Paulo, São Paulo, Brazil, 2004.

[72] R. B. Singer and M. Sazima, "Flower morphology and pollination mechanism in three sympatric Goodyerinae orchids from southeastern Brazil," Annals of Botany, vol. 88, no. 6, pp. 989 997, 2001.

[73] E. R. Pansarin, V. Bittrich, and M. C. E. Amaral, "At daybreak-reproductive biology and isolating mechanisms of Cirrhaea dependens (Orchidaceae)," Plant Biology, vol. 8, no. 4, pp. 494-502, 2006.

[74] E. R. Pansarin and M. C. E. Amaral, "Reproductive biology and pollination of southeastern Brazilian Stanhopea Frost ex Hook. (Orchidaceae)," Flora, vol. 204, no. 3, pp. 238-249, 2009.

[75] M. Sazima, S. Vogel, A. Cocucci, and G. Hausner, "The perfume flowers of Cyphomandra (Solanaceae): pollination by euglossine bees, bellows mechanism, osmophores, and volatiles," Plant Systematics and Evolution, vol. 187, no. 1-4, pp. 51-88, 1993.
[76] C. Gracie, "Pollination of Cyphomandra endopogon var. endopogon (Solanaceae) by Eufriesea spp. (Euglossini) in French Guiana," Brittonia, vol. 45, no. 1, pp. 39-46, 1993.

[77] S. C. Cappellari and B. Harter-Marques, "First report of scent collection by male orchid bees (Hymenoptera: Apidae: Euglossini) from terrestrial mushrooms," Journal of the Kansas Entomological Society, vol. 83, no. 3, pp. 264-266, 2010.

[78] D. W. Roubik and J. D. Ackerman, "Long-term ecology of euglossine orchid-bees (Apidae: Euglossini) in Panama," Oecologia, vol. 73, no. 3, pp. 321-333, 1987.

[79] R. W. Pemberton and G. S. Wheeler, "Orchid bees don't need orchids: evidence from the naturalization of an orchid bee in Florida," Ecology, vol. 87, no. 8, pp. 1995-2001, 2006.

[80] A. M. Basilio, D. Medan, J. P. Torretta, and N. J. Bartoloni, "A year-long plant-pollinator network,” Austral Ecology, vol. 31, no. 8, pp. 975-983, 2006.

[81] T. Petanidou, A. S. Kallimanis, J. Tzanopoulos, S. P. Sgardelis, and J. D. Pantis, "Long-term observation of a pollination network: fluctuation in species and interactions, relative invariance of network structure and implications for estimates of specialization," Ecology Letters, vol. 11, no. 6, pp. 564-575, 2008.

[82] C. M. Pigozzo and B. F. Viana, "Estrutura da rede de interações entre flores e abelhas em ambiente de Caatinga," Oecologia Brasiliensis, vol. 14, no. 1, pp. 100-114, 2010.

[83] G. M. D. M. Santos, C. M. L. Aguiar, and M. A. R. Mello, "Flower-visiting guild associated with the Caatinga flora: trophic interaction networks formed by social bees and social wasps with plants," Apidologie, vol. 41, no. 4, pp. 466-475, 2010.

[84] J. C. Biesmeijer, E. J. Slaa, M. S. Castro, B. F. Viana, A. M. P. Kleinert, and V. L. Imperatriz-Fonseca, "Connectance of Brazilian social bee: food plant networks is influenced by habitat, but not by latitude, altitude or network size," Biota Neotropica, vol. 5, no. 1, pp. 85-93, 2005.

[85] D. P. Vázquez and M. A. Aizen, "Asymmetric specialization: a pervasive feature of plant-pollinator interactions," Ecology, vol. 85 , no. 5, pp. 1251-1257, 2004.

[86] J. Bascompte, P. Jordano, and J. M. Olesen, "Asymmetric coevolutionary networks facilitate biodiversity maintenance," Science, vol. 312, no. 5772, pp. 431-433, 2006.

[87] M. Stang, P. G. L. Klinkhamer, and E. Van Der Meijden, "Size constraints and flower abundance determine the number of interactions in a plant-flower visitor web," Oikos, vol. 112, no. 1, pp. 111-121, 2006.

[88] K. M. Kay and D. W. Schemske, "Pollinator assemblages and visitation rates for 11 species of neotropical costus (Costaceae)," Biotropica, vol. 35, no. 2, pp. 198-207, 2003.

[89] D. W. Roubik, D. Yanega, M. Aluja, S. L. Buchmann, and D. W. Inouye, "On optimal nectar foraging by some tropical bees (Hymenoptera: Apidae),” Apidologie, vol. 26, no. 3, pp. 197211, 1995.

[90] D. W. Inouye, "Flight temperatures of male euglossine bees (Hymenoptera: Apidae: Euglossini)," Journal of the Kansas Entomological Society, vol. 48, no. 3, pp. 366-370, 1975.

[91] N. Myers, R. A. Mittermeier, C. G. Mittermeier, G. A. B. Fonseca, and J. Kent, "Biodiversity hotspots for conservation priorities," Nature, vol. 403, no. 6772, pp. 853-858, 2000. 

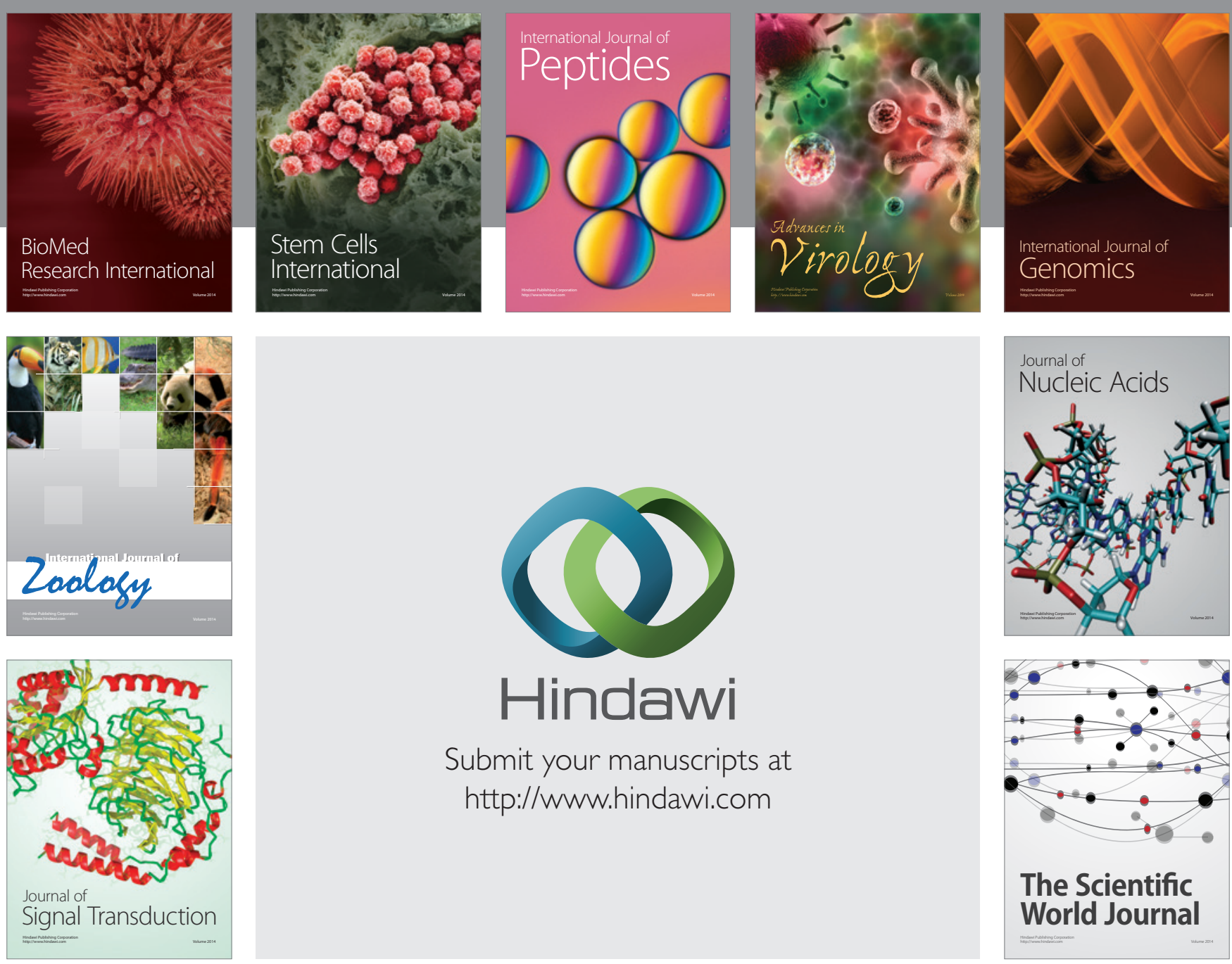

Submit your manuscripts at

http://www.hindawi.com
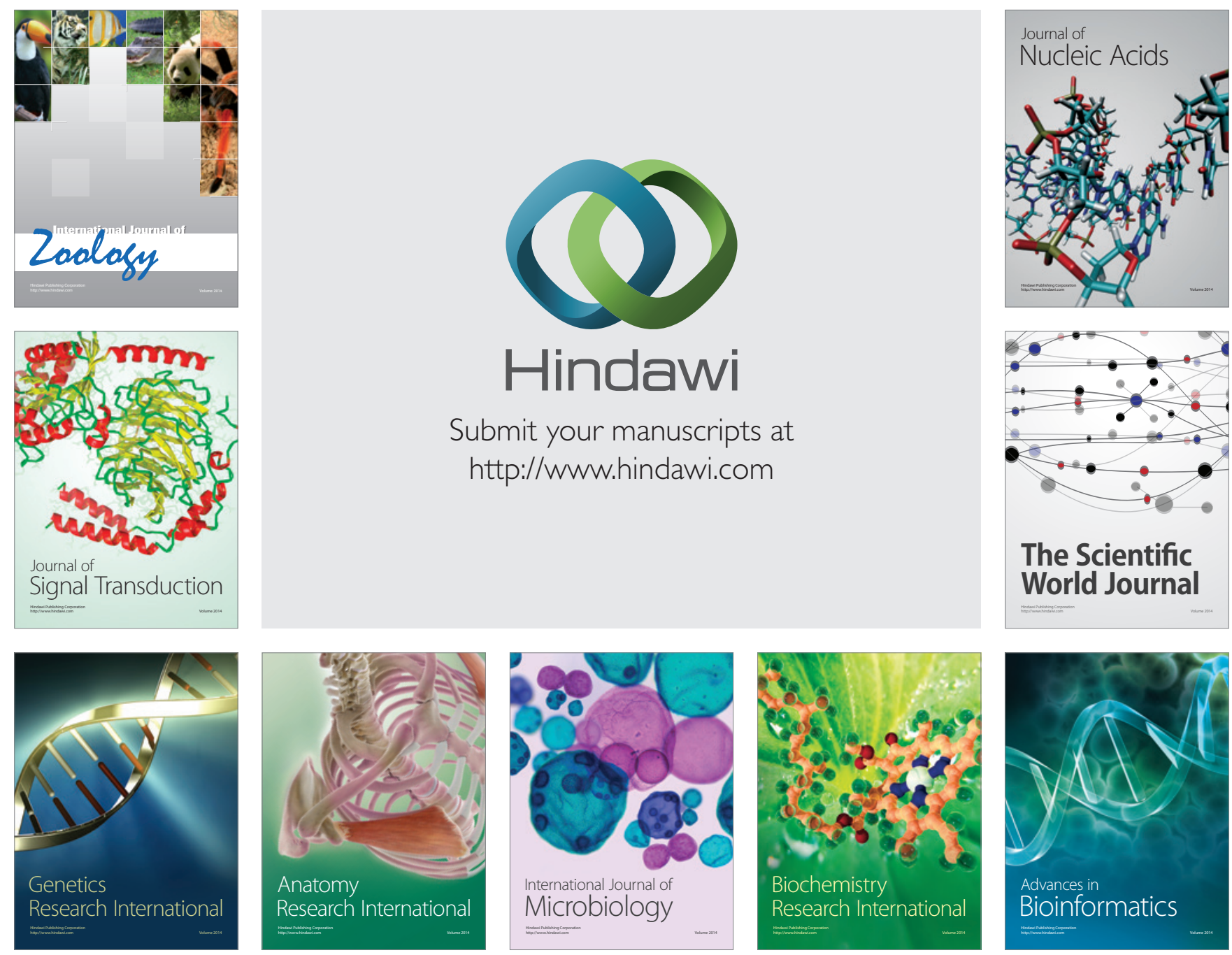

The Scientific World Journal
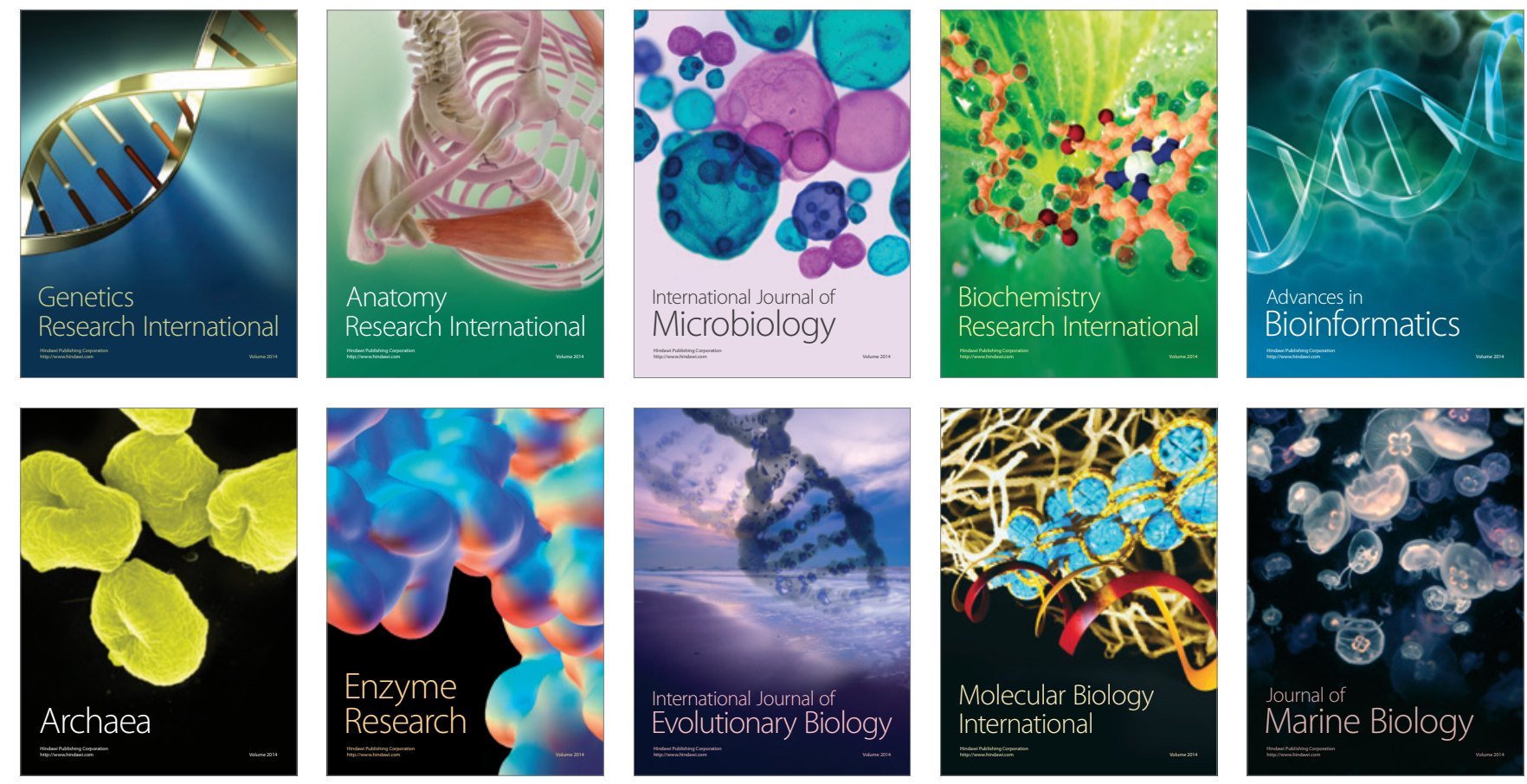